\title{
Overview of Runoff of March 11, 1995, in Fortymile Wash and Amargosa River, Southern Nevada
}

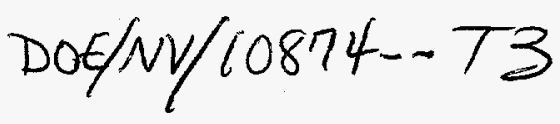

U.S. Department ofthe fôteliol-U.S. Geological Survey

Yucca Mountain, approximately 120 miles northwest of Las Vegas, Nev., is being studied by the U.S. Department of Energy as a potential repository for long-term storage of the Nation's high-level nuclear waste. This site-characterization study includes elements pertaining to surface-water runoff, including the potential for flooding. The U.S. Geological Survey (USGS), in cooperation with the U.S. Department of Energy, is monitoring streamflow in southern Nevada through a network of streamflow gaging stations and miscellaneous streamflow measurements in support of the site-characterization effort.

Yucca Mountain and much of the western part of the Nevada Test Site (NTS) are part of the Amargosa River drainage. The Amargosa River is a major drainage component (over 5,000 $\mathrm{mi}^{2}$ ) of the unique closed-basin, hydrologic regime known as the Great Basin. Fortymile Wash and Beatty Wash (fig. 2) are the major tributaries to the upper Amargosa River, which drains through several small, populated areas downstream. This river system terminates in Death Valley, a National monument with an expanding tourist population.

The rugged and sparsely vegetated Amargosa River drainage is within the rainshadow of the Sierra Nevada. As a result of dry, semi-arid, continental climate, flow of the Amargosa River is ephemeral except in a few relatively short reaches where discharging springs maintain small, perennial base flows. Prior to Yucca Mountain site-characterization studies, few data were available on the streamflow of the Amargosa River and its major tributaries. Flow characteristics of the basin are generally poorly understood.

Near U.S. Highway 95, the Fortymile Wash channel changes from being moderately confined to several distributary channels that are poorly confined. This poorly-defined, distributary- drainage pattern persists downstream to its confluence with the Amargosa River. Streamflow losses to infiltration and evaporation within this reach are high (Savard and Beck, 1995). The Amargosa River is likewise moderately confined upstream from the Big Dune (fig. 2). Downstream from the Big Dune, the river splits into several channels that are poorly defined through the Amargosa Valley farm area. These areally abrupt changes in flow-pattern and channel-geometry characteristics of Fortymile Wash and the Amargosa River, wherein moderately- to welldefined channels evolve downstream into poorly defined channels, cause uncertainty regarding flow continuity within and between the two drainages. Major questions throughout the Yucca Mountain site-characterization studies are whether, under the present climatic regime, Fortymile Wash is capable of flowing to the Amargosa River, and whether Amargosa River is similarly capable of flowing from its source to Death Valley.

The runoff of March 11, 1995, provided answers to these questions about flow continuity. Precipitation associated with a weather disturbance moving eastward from California caused the most extensive regional runoff in Fortymile Wash and Amargosa River (fig. 2) since February 1969. Preliminary data reported for selected USGS and NTS rain gages within the study area showed that cumulative precipitation ranged from about 2 to 6 inches during March 9-11, with the larger amounts falling at the higher-altitude sites. Eyewitness accounts of snowpack conditions on Timber Mountain and Pahute Mesa just before and after the storm indicate that, in addition to rainfall, high-altitude snowmelt probably contributed to the volume of runoff in Fortymile Wash and Beatty Wash.

The runoff of March 11 is important because it represents the first documented case during site-characterization studies in which Fortymile Wash and Amargosa River flowed

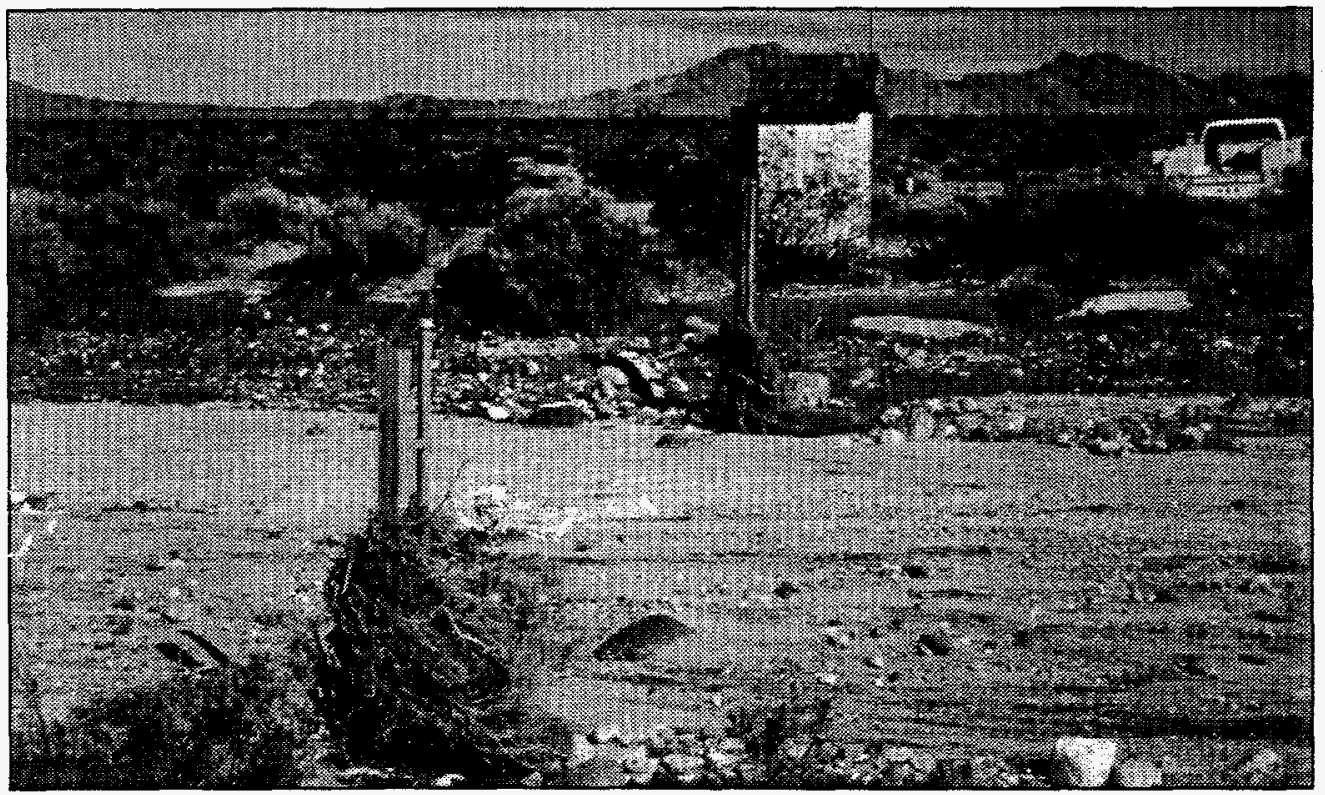

Figure 1. Evidence of debris-laden runoff of March 11, 1995, at Fortymile Wash near Amargosa Valley streamflow gaging station above U.S. Highway 95. 


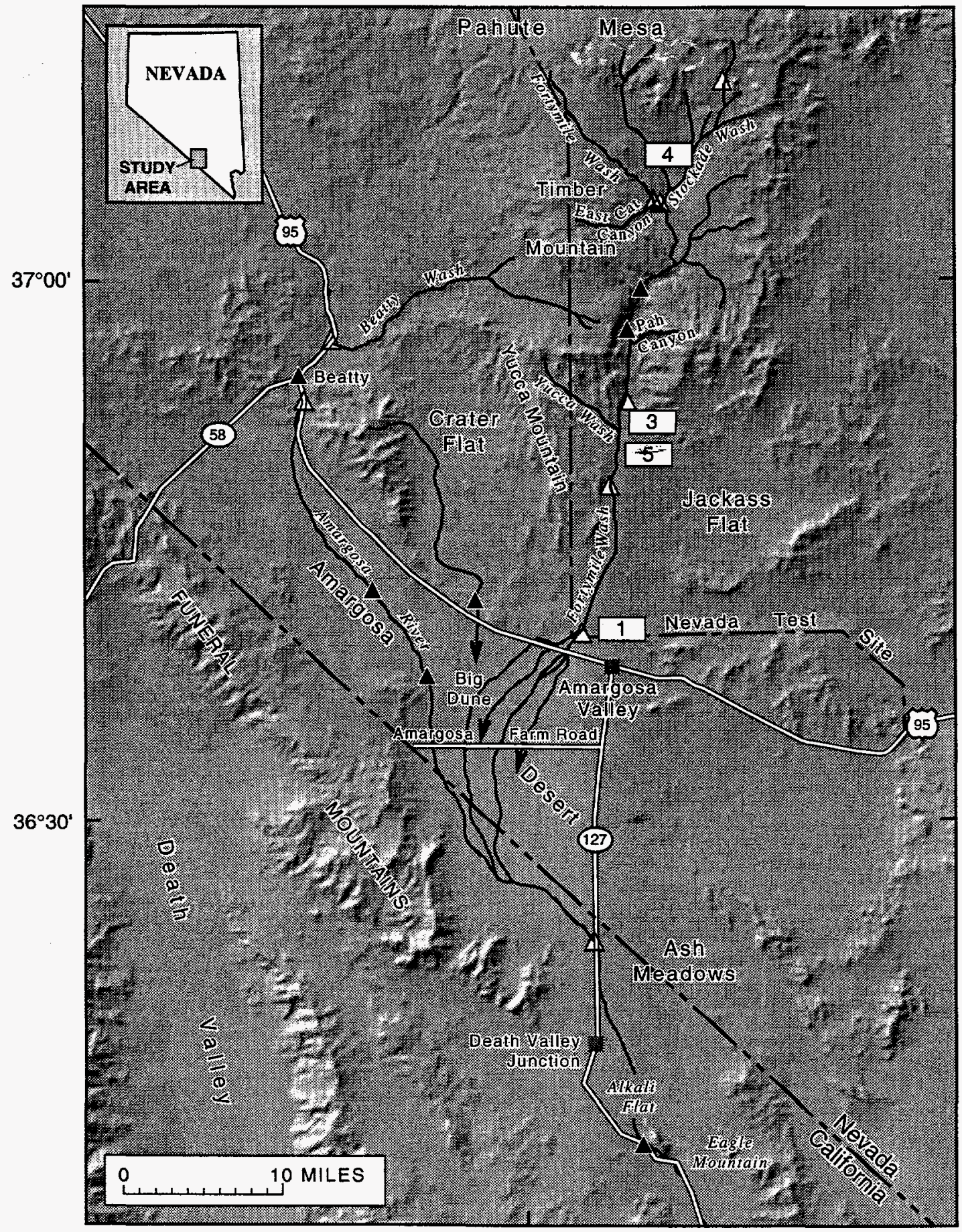

EXPLANATION

\section{$\triangle$ Streamflow recording site}

$\Delta$ Miscellaneous streamflow measurement site

\section{Stream channel with flow on} MARCH 11, 1995

\section{Approximate location of photo-}

araph-Number corresponds to

Figure 2. Geographic setting and surface flow paths during the March 11, 1995, runoff in Fortymile Wash and Amargosa River. 


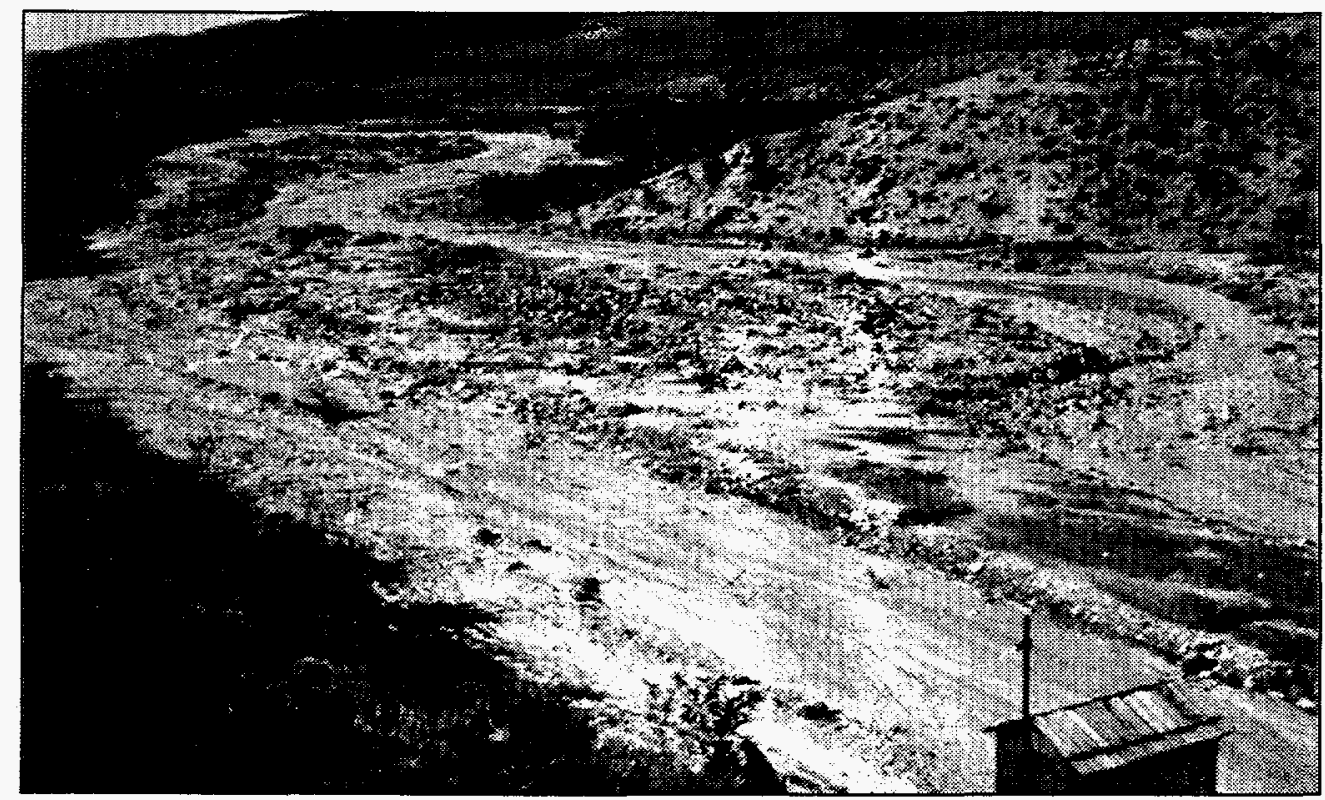

Figure 3. Bank erosion and sediment deposition in Fortymile Wash at Narrows as a result of runoff of March 11, 1995.

simultaneously throughout their entire Nevada reaches. These two fluvial systems were last reported to have flowed extensively within Nevada in February 1969 before site characterization started. The 1969 flood is overall the largest known in the Amargosa River system during the last 25 years. Flow in Fortymile Wash was first documented during site-characterization studies in March 1983, shortly before the initial streamflow gaging stations were installed. The Wash had flow again three times during July and August 1984 as the result of severe but localized convective storms. The extent of flows beyond the boundaries of NTS were not investigated for these early 1980's runoffs.

A field reconnaissance after the storm of March 1995 indicated moderate runoff throughout Fortymile Wash (figs. 1 and 2), several of its main tributaries (East Cat Canyon Wash, Stockade Wash, Pah Canyon Wash, and Yucca Wash), and several minor tributaries that drain the eastern flank of Yucca Mountain (fig. 2). The Amargosa River also flowed, from above Beatty past the California-Nevada state line, with a large percentage of the flow contributed by Beatty Wash (fig. 2).

The duration of flow in Fortymile Wash was approximately 10 to 12 hours. U.S. Highway 95 was closed from about 8:00 a.m. to about 5:30 p.m. on March 11 because of the streamflow (Trooper William Graham, Nevada Highway Patrol, oral communication, 1995). All evidence indicated heavy debris transport. Bank erosion and sediment deposition were observed along most of Fortymile Wash (fig. 3) within the NTS with sediment deposits as thick as 5 feet in some areas. Other effects of the Fortymile Wash runoff include damage to the Stockade Wash culverts at Airport Road on Pahute Mesa (fig. 4), sediment deposition on $\mathrm{H}$ Road where it crosses Fortymile Wash east of Yucca Mountain (fig. 5) and on Amargosa Farm Road in Amargosa Valley. A near tragedy occurred at the H-Road crossing when an NTS worker was swept away by an initial flow surge while attempting to cross Fortymile Wash during the early morning of March 11. His account of the event described the surge as a "5- to 6-foot wall of water and clattering rocks" followed by a rapidly rising water level that moved at high velocities (Augustine Passalacqua, TRW Environmental Safety Systems, Inc., oral communication, 1995).
Amargosa River runoff duration was also approximately 10 to 12 hours. Minor bank erosion and sediment deposition were observed along the Amargosa River from Beatty to Amargosa Valley. Amargosa Farm Road acquired additional sediment deposits as a result of the Amargosa River flow.

Peak flow in Fortymile Wash was significantly attenuated when the flow split into several distributary channels near U.S. Highway 95. Peak flow was attenuated further when a part of the distributed flow was diverted to the west for about 6 miles along the north shoulder of U.S. Highway 95 before turning southward again. The Amargosa River peak flow attenuated between Beatty and Big Dune. Downstream from Big Dune, the flow turned southward and split into several shallow distributary channels through the Amargosa Valley farm area.

Peak flows for Fortymile Wash and Amargosa River were again attenuated at the confluence of the two streams near the southeast end of the Funeral Mountains. Flow within this broad, flat confluence area was slow and shallow (only inches deep) owing to the absence of well-defined channels and the low landsurface gradient. The merged flow of Fortymile Wash and Amargosa River converged into a shallowly incised, wellvegetated channel just upstream of California Highway 127 and flowed into the broad Alkali Flat near Death Valley Junction. The combined Fortymile Wash and Amargosa River runoff flowed through Alkali Flat where it combined with other runoff to the Amargosa River caused by localized precipitation near Eagle Mountain.

The information provided by the USGS surface-water monitoring program documented flow from the headwater areas of Fortymile and Beatty Washes, and the combineci flow downstream past Death Valley Junction that resulted from moderate runoff. This documentation confirms that Fortymile Wash and Amargosa River have the potential, in the present climatic regime, to transport dissolved and particulate material beyond the confines of NTS and the Yucca Mountain areas during moderate and more severe streamflow.

-David A. Beck and Patrick A. Glancy 


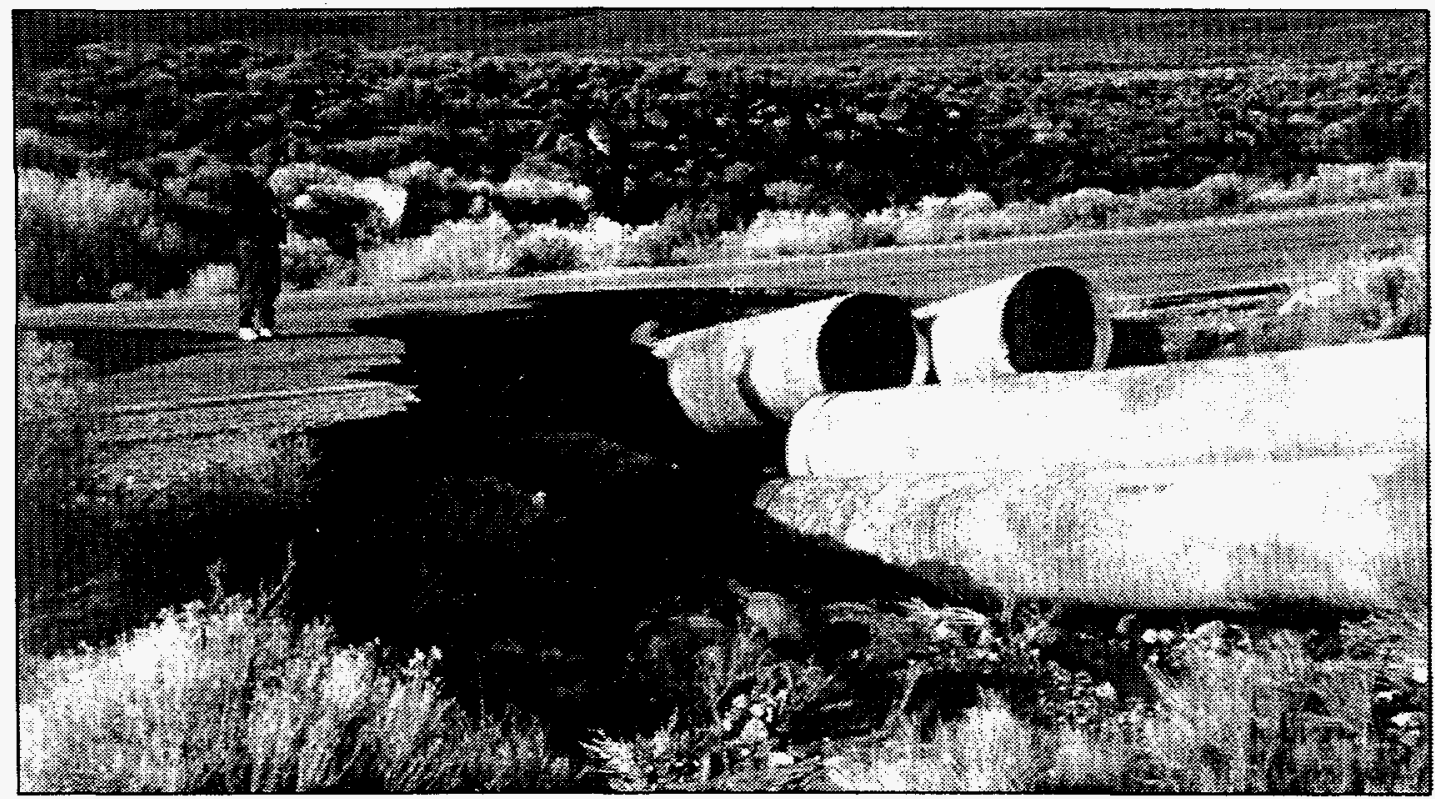

Figure 4. Culvert damage from runoff of March 11, 1995, along Stockade Wash at Airport Road, Nevada Test Site.

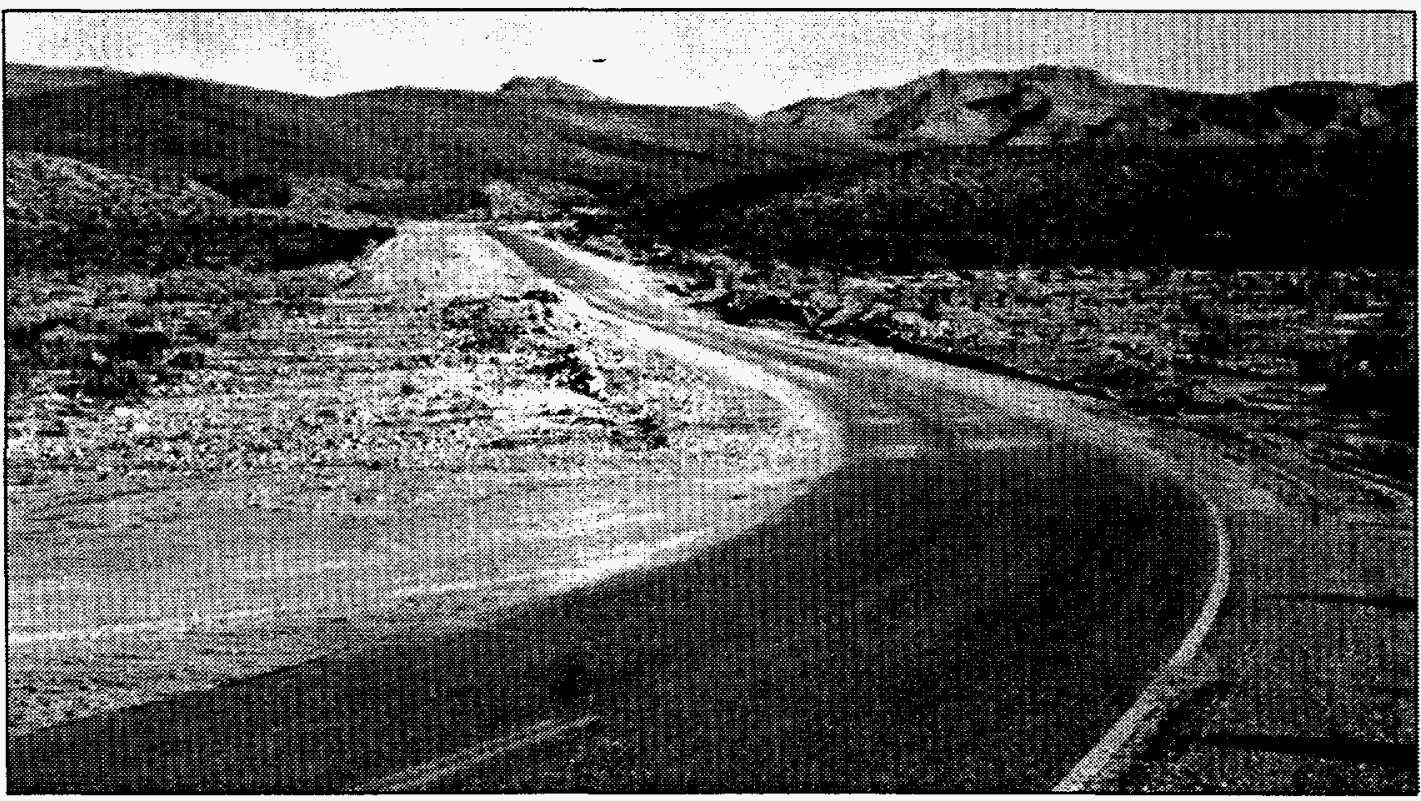

Figure 5. H-Road Crossing Fortymile Wash, Nevada Test Site. Debris from runoff of March 11, 1995, was bulldozed to both shoulders of the road. Site is where NTS worker was swept downstream.

\section{Selected References}

Kane, T.G., Bauer, D.J., and Martinez, C.M., 1994, Streamflow and selected precipitation data for Yucca Mountain region, southern Nevada and eastern California, water years 1986-90: U.S. Geological Survey Open-File Report 94-312, 118 p.

Pabst, M.E., Beck, D.A, Glancy, P.A., and Johnson, J.A., 1993, Streamflow and selected precipitation data for Yucca Mountain and vicinity, Nye County, Nevada, water years 1983-85: U.S. Geological Survey Open-File Report 93-438, $66 \mathrm{p}$.

Savard, C.S., and Beck, D.A., 1994, Transmission losses in Fortymile Wash near Yucca Mountain, Nevada [abs.]: Eos, American Geophysical Union Transaction, v. 75, no. 44, p. 283
U.S. Geological Survey, 1994-95, Water resources data, Nevada, water years 1993-94: U.S. Geological Survey Water-Data Reports NV-93-1 to NV-94-1 (published annually).

\section{For more information about the Yucca Mountain surface-water studies, contact:}

David A. Beck

U.S. Geological Survey

6770 S. Paradise Road

Las Vegas, NV 89119

(702) 897-4005

dabeck@usgs.gov 


\section{DISCLAIMER}

This report was prepared as an account of work sponsored by an agency of the United States Government. Neither the United States Government nor any agency thereof, nor any of their employees, makes any warranty, express or implied, or assumes any legal liability or responsibility for the accuracy, completeness, or usefulness of any information, apparatus, product, or process disclosed, or represents that its use would not infringe privately owned rights. Reference herein to any specific commercial product, process, or service by trade name, trademark, manufacturer, or otherwise does not necessarily constitute or imply its endorsement, recommendation, or favoring by the United States Government or any agency thereof. The views and opinions of authors expressed herein do not necessarily state or reflect those of the United States Government or any agency thereof. 


\section{DISCLAMMER}

Portions of this document may be illegible in electronic image products. Images are produced from the best available original document. 